\title{
Effect of Intercropping Beans with Maize and Botanical Extract on Fall Armyworm (Spodoptera frugiperda) Infestation
}

\author{
Clovis Bessong Tanyi $\left(\mathbb{D},{ }^{1,2}\right.$ Raymond Ndip Nkongho, ${ }^{1}$ Justin Nambangia Okolle, ${ }^{3}$ \\ Aaron Suh Tening, ${ }^{1}$ and Christopher Ngosong ${ }^{1}{ }^{1}$ \\ ${ }^{1}$ Department of Agronomic and Applied Molecular Sciences, Faculty of Agriculture and Veterinary Medicine, University of Buea, \\ P.O.Box 63, Buea, South West Region, Cameroon \\ ${ }^{2}$ St. Louis Higher Institute of Agriculture, P.O.Box 10275, Douala, Littoral Region, Cameroon \\ ${ }^{3}$ Institute of Agricultural Research for Development (IRAD), Ekona, P.M.B 25, Buea, South West Region, Cameroon
}

Correspondence should be addressed to Clovis Bessong Tanyi; ctanyi@stlouis-group.org

Received 30 December 2019; Accepted 2 May 2020; Published 26 May 2020

Academic Editor: Adriano Sofo

Copyright (C) 2020 Clovis Bessong Tanyi et al. This is an open access article distributed under the Creative Commons Attribution License, which permits unrestricted use, distribution, and reproduction in any medium, provided the original work is properly cited.

\begin{abstract}
African farmers are currently grappling with potential control measures for the invasive fall armyworm (FAW) (Spodoptera frugiperda), which has recently emerged as an important economic pest that is ravaging maize fields across the continent. We evaluated the efficacy of the West African black pepper extract and beans intercropping systems as viable FAW control measures and the implication on maize yields. The experiment comprised five treatments (control-no input, dwarf beans intercrop, climbing beans intercrop, West African black pepper extract, and insecticide) with three replications each. FAW severity was assessed at three to seven weeks after planting (WAP), while maize infestation was assessed at seven WAP. FAW severity increased significantly $(P<0.05)$ across WAP for the control and dwarf beans intercrop, with the highest at four and six WAP, respectively. FAW severity also differed $(P<0.05)$ significantly across treatments at four to seven WAP, with the lowest recorded in the extract of West African black pepper (Piper guineense) and the highest in control treatments. Maize infestation ranged from 13 to $93 \%$, with the lowest in the West African black pepper extract and synthetic insecticide, followed by both dwarf and climbing beans intercrops and then the control. The maize yield determined at physiological maturity ranged from 2.2 to $6.3 \mathrm{t}$ ha ${ }^{-1}$ across treatments and differed significantly, with the highest in the West African black pepper extract and synthetic insecticide, followed by both the dwarf and climbing beans intercrops, as compared to the control. Overall, the West African black pepper extract and beans push cropping systems demonstrated efficacy as viable sustainable alternative control measures for the invasive fall armyworm in maize fields.
\end{abstract}

\section{Introduction}

Global food insecurity is a chronic issue that is likely to deteriorate with further decrease in soil fertility coupled with increase in pest and disease pressures. Maize (Zea mays L.) production contributes to food security and income generation for many smallholder farmers in sub-Saharan Africa (SSA) [1]. However, maize production is constrained by combinations of poor mineral nutrition [2] and insect pests $[3,4]$. Recent emergence of the invasive fall armyworm (FAW) Spodoptera frugiperda (Lepidoptera: Noctuidae) in
Africa has overshadowed the stem borer Busseola fusca (Lepidoptera: Noctuidae) as the major insect pest of maize $[3,5]$. FAW is a polyphagous pest with a wide host range and a long-distance migratory pest that is capable of flying over $100 \mathrm{~km}$ in a single night $[6,7]$. FAW feeds on young maize leaf whorls, ears, and tassels, causing substantial damage with occasional total yield loss [8, 9]. FAW larvae cause crop damage while adults ensure rapid spread of the pest by flying across long distances and rapidly reproducing [10]. FAW is an important economic pest of maize in its native Americas [11], which has recently extended its ecological niche by 
invading Africa [12-15]. Accordingly, FAW was recently reported in a maize field in Cameroon and has rapidly spread across the different agroecological zones of the country $[16,17]$, and farmers are seemingly using various management options including synthetic insecticides to grapple with the invasive pest. Although synthetic insecticides are commonly used to control field pests, their continuous use can result in pest resistance and increased reliance on chemical controls that may lead to high production cost and severe environmental effects $[18,19]$. Therefore, a holistic approach is necessary for the control of the FAW pest in maize fields that integrates sustainable alternative management strategies and are adapted to the specific needs of farmers, especially small-scale subsistence farmers in SSA who lack financial resources and technological know-how.

Potential sustainable pest management strategies include intercropping systems and use of beneficial microbes and botanical pesticides $[5,20,21]$. Intercropping constitutes push-pull systems involving companion plants that act as the "push" component for pests, or planting companion plants at the boarders of main crops to act as the "pull" component [22-24]. Some companion plants release semiochemicals that either repel insect pests from the main crop (e.g., push system) or attract insect pests away from the main crop (e.g., pull system) by providing better niches and food resources [25]. The cultivation of grain legumes such as beans (Phaseolus vulgaris L.) as the companion crop can provide a different ecological niche for the FAW larvae while also emitting semiochemicals that may deter FAW and oviposition [26]. Legume intercropping is widely encouraged as a viable integrated soil fertility management strategy [27, 28] as legumes can also serve as a push factor against insect pests $[24,25]$. Some plant bioactive materials have also demonstrated efficacy as botanical insecticides for the control of various insect pests of economic importance [26, 29]. Besides direct effects on pests, companion crops and botanicals can enhance the population of natural enemies of field pests. Contrary to large-scale industrial monoculture farming systems, intercropping systems are common with smallscale subsistence farming systems and the smallholder farmers inevitably need viable information on sustainable management options that enhance productivity and environmental protection. Hence, this study was intended to evaluate the direct and indirect effects of the West African black pepper extract and beans push cropping systems as sustainable alternative control measures for the invasive FAW in maize fields. It was hypothesised that the extract of West African black pepper and beans intercropping systems shall exert adverse effects on FAW with reduced severity and infestation leading to higher maize yield.

\section{Materials and Methods}

2.1. Experimental Site and Setup. This study was conducted between August and November 2018 on a smallholder farm in Molyko, Buea, Cameroon, situated between latitudes $4^{\circ} 3^{\prime} \mathrm{N}$ and $4^{\circ} 12^{\prime} \mathrm{N}$ and longitudes $9^{\circ} 12^{\prime} \mathrm{E}$ and $9^{\circ} 20^{\prime} \mathrm{E}$. The soil is derived from weathered volcanic rocks, and Buea has a monomodal rainfall regime with less pronounced dry season and $86 \%$ relative humidity. The dry season is from November to March with a mean annual rainfall of $2800 \mathrm{~mm}$, and mean monthly air temperature ranging from 19 to $30^{\circ} \mathrm{C}$. Soil temperature at $10 \mathrm{~cm}$ depth decreases from 25 to $15^{\circ} \mathrm{C}$ with increasing elevation from 200 to $2200 \mathrm{~m}$, respectively, above sea level [27, 30, 31].

The experiment comprised five treatments (control-no input, dwarf beans intercrop, climbing beans intercrop, West African black pepper extract, and synthetic insecticide) arranged in a randomized complete block design with three replications each. The field site was cleared manually using a cutlass and partitioned into fifteen experimental plots measuring $3 \times 4 \mathrm{~m}\left(12 \mathrm{~m}^{2}\right)$ each, with $1 \mathrm{~m}$ untilled buffer zones separating the plots from each other. Plots were tilled manually at about $30 \mathrm{~cm}$ soil depth using a hoe.

2.2. Crop Cultivation. Three seeds of maize and dwarf or climbing beans (Phaseolus vulgaris L.) purchased from an agroshop in Buea, Cameroon, were planted at $80 \times 50 \mathrm{~cm}$ inter- and intrarow spacing and later thinned to two vigorous seedlings per stand. Each maize monoculture plot had 60 plants while the intercropped plots additionally comprised 60 dwarf or climbing beans plants arranged in six alternate rows with five stands per row, giving a total of 120 plants. The dwarf and climbing beans were intercropped with maize as a biocontrol strategy to serve as the push component against fall armyworm. All the experimental plots were amended twice at two and four weeks after germination using a granular inorganic fertilizer (NPK 20:10:10) at $5 \mathrm{~g}$ per plant by ringing at $5 \mathrm{~cm}$ from the plant. Soil moisture during the entire experiment depended on the local rainfall regime, while weed emergence was monitored regularly and weeded manually using a hoe.

\subsection{Application of Botanical Extract and Synthetic Insecticide.} Maize plants were protected against fall armyworm using companion bean plants as the intercrop (see Section 2.2) or the West African black pepper extract or synthetic insecticide. The West African black pepper extract and insecticide (K-Optimal: SCPA SIVEX International ${ }^{\circledR}$ France, comprising lambda-cyhalothrin $15 \mathrm{~g} / \mathrm{l}+20 \mathrm{~g} / \mathrm{L}$ acetamiprid active ingredients) were applied at about $0.03 \mathrm{ml}$ per plant on the respective plots using a knapsack sprayer. The West African black pepper extract was produced using dry seeds of Piper guineense that were crushed using a kitchen blender to produce fine powder [29]. $200 \mathrm{~g}$ Piper power was dissolved in $0.25 \mathrm{~L}$ vegetable oil (KING’S${ }^{\circledR}$, Lagos, Nigeria) and $25 \mathrm{~g}$ detergent $\left(\mathrm{SABA}^{\circledR}\right.$, Douala, Cameroon) was added and then was thoroughly stirred to produce a sticky emulsion and stored in a plastic container at room temperature prior to laboratory and field tests. For weekly field application, $16.7 \mathrm{ml}$ of the West African black pepper extract was filtered into $5 \mathrm{~L}$ water using a double 169 -folded muslin cloth and stirred thoroughly to achieve homogeneity before spraying on the maize plants. 
2.4. Laboratory Bioassay of West African Black Pepper Extract against FAW. Bioassays were conducted on FAW larvae at the laboratory of the Faculty of Agriculture and Veterinary Medicine, University of Buea, Cameroon. The mortality test was performed to determine the appropriate concentration of the West African black pepper extract for use to obtain the best field result. For the laboratory test, FAW larvae of approximately equal sizes were randomly collected from maize fields in Buea, and six larvae were placed in each petri dish. Maize leaves were harvested from the fields, and $0.02 \mathrm{~g}$ (fresh weight) was added into each petri dish as the food substrate for the larvae. Six treatments were prepared including a control (only tap water) and five concentrations of the West African black pepper extract: 0.007 (100:15), 0.005 (80:15), 0.004 (60:15), 0.003 (50:15), 0.001 (20:15), and $0.00(0: 15)$ product : water $(\mathrm{ml}: \mathrm{L})$ ratio (Table 1$)$. A syringe was used to apply the different concentrations of the West African black pepper extract into petri dishes containing FAW larvae, and their toxicity was observed over two hours (120 minutes).

\subsection{Data Collection}

2.5.1. Severity of Fall Armyworm and Maize Infestation. Fall armyworm is a defoliating maize pest that can have many generations per year depending on environmental conditions. Adult females can live 10-21 days and lay up to
1,000 egg masses in their lifetime. Eggs are laid in batches of 100-200 eggs that hatch within 2-4 days with six larval stages lasting 14-22 days, while the pupal stage lasts 8-30 days. The pest ecology and environmental conditions influence their severity and infestation of host crops. FAW larval specimens were examined on the head capsule and abdominal segments for the occurrence of peculiar distinguishing characteristics. Both brown and light green FAW larvae were identified based on visual observation of characteristic marks and dotted spots such as inverted " $Y$ " marking on the head area, four large dorsal spots in a near square arrangement on the second last segment, lighter dorsal area, pale dorsal line, pale laterodorsal line, and lighter ventral area $[28,32]$. The weekly FAW severity (e.g., mean number of larvae per plant \pm standard deviation (SD)) was recorded on seven randomly selected plants at three to seven weeks after planting (WAP). FAW severity was assessed on the entire plant, especially on leaves and leaf whorls. FAW infestation (e.g., number of infested maize plants per plot) was also assessed at seven weeks after planting. All the sixty plants on each plot were visually observed for symptoms of FAW larval damage on leaves and leaf whorls (e.g., small holes, scratches, or skeleton damage of leaves with partially damaged epidermis giving a windowpane appearance). The rate of FAW maize infestation (mean $\% \pm \mathrm{SD}$ ) was calculated as a percentage ratio of infested plants per plot to the total number of plants:

$$
\text { Maize infestation by fall armyworm }(\%)=\frac{\text { number of infested plants per plot }}{\text { total number of plants per plot }} \times 100 \text {. }
$$

2.5.2. Assessment of Maize Yield. Ten maize plants were randomly harvested (15 November 2018) from each plot at physiological maturity, and the number of cobs and cob length (measured using a calibrated tape) was recorded per plant. Maize cobs were manually threshed by hand, and grains were oven-dried at $60^{\circ} \mathrm{C}$ for five days, and the dry weight (g) was recorded on a scale balance to calculate the total yield in $\mathrm{t} \mathrm{ha}^{-1}$. The 1000-grain weight (g) was also recorded for randomly selected maize grains from each plot.

2.6. Statistical Analysis. Data sets were subjected to statistical analyses using STATISTICA 9.1 for Windows [33]. The dependent variables (e.g., fall armyworm severity, maize infestation, and maize yield parameters) were subjected to analysis of variance (ANOVA, $P<0.05$ ) to test the effects of treatments $(n=5)$ as categorical predictors. The significant data means were compared by Tukey's HSD $(P<0.05)$, and where applicable, Spearman rank correlation $(P<0.05)$ was performed to determine the degree of association between dependent variables and categorical predictors.

\section{Results}

3.1. Laboratory Bioassay of West African Black Pepper Extract against FAW. The laboratory mortality of FAW increased at higher concentrations of the West African black pepper extract, with early larval mortality observed after 40 minutes and total mortality after 60 minutes, except for the lowest concentration $(0.001 \mathrm{ml})$ of the West African black pepper extract (Table 1). By contrast, no such larval mortality occurred in the tap water control treatment. Based on this larval mortality evaluation, the concentration of $0.003 \mathrm{ml}$ of the West African black pepper extract was considered as the most cost effective, and it was adopted for field application.

3.2. Fall Armyworm Severity and Maize Infestation. The severity of fall armyworm differed $(P<0.001)$ significantly across treatments, weeks after planting, and in their interaction. FAW severity increased significantly across weeks after planting for the control and dwarf beans intercrop, with the highest severity at four and six weeks after planting, respectively $(P<0.05$; Table 2$)$. FAW severity also differed $(P<0.05)$ significantly between treatments at four to seven weeks after planting, with the lowest severity recorded in the West African black pepper extract, and the highest severity in control treatments. Maize infestation ranged from 13 to 93\% across treatments at seven weeks after planting and differed $(P<0.05)$ significantly, with the highest infestation in the control, followed by the dwarf and climbing beans intercrops (Figure 1). The lowest maize infestation was 
TABLE 1: Laboratory bioassay of five concentrations of the West African black pepper extract against fall armyworm (FAW).

\begin{tabular}{lccccccc}
\hline \multirow{2}{*}{ Concentrations of Piper emulsion (ml) } & \multicolumn{9}{c}{ Time-dependent FAW mortality (minutes) } & \multicolumn{2}{c}{ Cumulative FAW mortality } \\
\hline 0.007 & 20 & 40 & 60 & 80 & 100 & 120 & 6 \\
0.005 & 0 & 4 & 2 & - & - & - & - \\
0.004 & 0 & 2 & 4 & - & - & - & 6 \\
0.003 & 0 & 2 & 4 & - & - & - & 6 \\
0.001 & 0 & 2 & 4 & - & - & 4 & 6 \\
0 (tap water) & 0 & 0 & 0 & 2 & 0 & 4 \\
\hline
\end{tabular}

FAW larval mortality in relation to tap water as the control.

TABLE 2: Effect of treatments on fall armyworm severity (number of larvae per plant; mean \pm SD) at three to seven weeks after planting.

\begin{tabular}{lccccc}
\hline Treatments & \multicolumn{3}{c}{ Weeks after planting } \\
& 3 & 4 & 5 & $2.9 \pm 0.3 \mathrm{bA}$ & $2.4 \pm 0.4 \mathrm{bcA}$ \\
Control-no input & $0.9 \pm 0.8 \mathrm{cA}$ & $4.7 \pm 0.7 \mathrm{aA}$ & $0.7 \pm 0.1 \mathrm{aB}$ & $1.4 \pm 0.4 \mathrm{aB}$ & $2.6 \pm 0.4 \mathrm{bcA}$ \\
Dwarf beans intercrop & $0.3 \pm 0.2 \mathrm{bA}$ & $1.3 \pm 0.5 \mathrm{aB}$ & $0.8 \pm 0.3 \mathrm{aB}$ & $0.9 \pm 0.8 \mathrm{aB}$ & $1.8 \pm 0.6 \mathrm{aAB}$ \\
Climbing beans intercrop & $1.0 \pm 1.4 \mathrm{aA}$ & $0.9 \pm 0.8 \mathrm{aB}$ & $0.1 \pm 0.1 \mathrm{aC}$ & $0.0 \pm 0.0 \mathrm{aC}$ & $0.0 \pm 0.0 \mathrm{aC}$ \\
Piper emulsion botanical & $0.2 \pm 0.3 \mathrm{aA}$ & $0.2 \pm 0.2 \mathrm{aB}$ & $\mathrm{aB}$ \\
Synthetic insecticide & $0.4 \pm 0.3 \mathrm{aA}$ & $0.3 \pm 0.2 \mathrm{aB}$ & $1.1 \pm 0.2 \mathrm{aB}$ & $0.3 \pm 0.5 \mathrm{aB}$ & $1.0 \pm 0.8 \mathrm{aB}$ \\
\hline
\end{tabular}

Values within rows with different lowercase letters are significantly different between weeks for each treatment, while values within columns with different uppercase letters are significantly different between treatments for each week $(p<0.05)$.

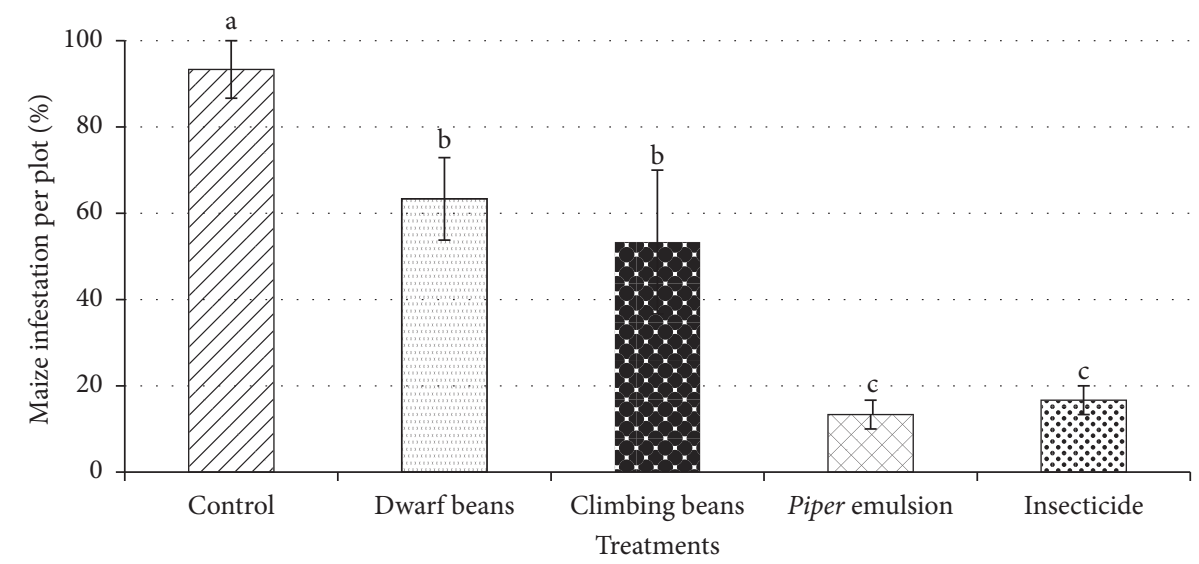

FIGURE 1: Effect of treatments on maize infestation (mean \pm SD) by fall armyworm at seven weeks after planting. Values with different letters are significantly different $(P<0.05)$.

recorded in the West African black pepper extract and synthetic insecticide treatments (Figure 1).

3.3. Impact of Treatments on Maize Yield. Maize grain yield ranged from 2.2 to $6.3 \mathrm{tha}^{-1}$ and differed significantly across treatments $(P<0.001)$, with the highest yield in the synthetic insecticide and the West African black pepper extract, followed by the dwarf and climbing beans intercrops, while the lowest yield occurred in the control (Figure 2). Maize yield was negatively correlated to FAW severity and the rate of infestation, as the maize yield decreased significantly with increased FAW severity $(r=-0.78, P<0.05)$ and infestation $(r=-0.83, P<0.05)$. The length of maize cobs ranged from 24.7 to $30.7 \mathrm{~cm}$ and differed significantly across treatments $(P<0.001)$, with the highest in the synthetic insecticide and climbing beans intercrop as compared to the control (Table 3 ). The weight of 1000 -maize grains ranged from 0.8 to $1.1 \mathrm{~g}$, but the grain weight did not $(P<0.05)$ differ between treatments (Table 3).

\section{Discussion}

4.1. Efficacy of Botanical Extract and Intercropping Systems against FAW. The observed efficacy of the synthetic insecticide is consistent with other reports, but overuse or misuse can lead to ecological backlashes such as resurgence and resistance $[34,35]$. Despite the efficacy of insecticides against FAW, their potential effects on nontarget organisms such as natural enemies could be inevitable [36, 37]. This highlights the importance of sustainable alternatives such as botanicals and legume intercropping [25]. Furthermore, 


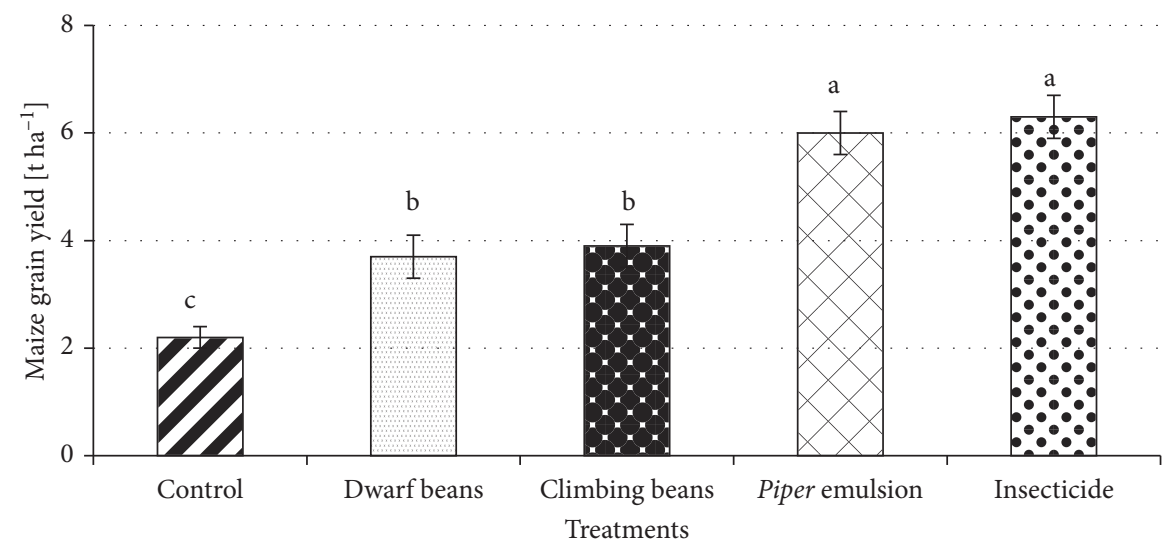

FIGURE 2: Impact of treatments on maize grain yield (mean $\pm \mathrm{SD})$. Values with different letters are significantly different $(P<0.05)$.

TABLE 3: Impact of treatments on the length of maize cobs and 1000 -grain weight.

\begin{tabular}{lcc}
\hline Treatments & $\begin{array}{c}\text { Cob length } \\
(\mathrm{cm})\end{array}$ & 1000-grain weight $(\mathrm{g})$ \\
\hline Control-no input & $24.7 \pm 0.7 \mathrm{~b}$ & $0.9 \pm 0.1 \mathrm{a}$ \\
Dwarf beans intercrop & $25.7 \pm 1.0 \mathrm{ab}$ & $0.8 \pm 0.0 \mathrm{a}$ \\
Climbing beans intercrop & $30.7 \pm 3.3 \mathrm{a}$ & $1.1 \pm 0.1 \mathrm{a}$ \\
Piper emulsion botanical & $29.3 \pm 1.0 \mathrm{ab}$ & $1.0 \pm 0.1 \mathrm{a}$ \\
Synthetic insecticide & $30.7 \pm 1.2 \mathrm{a}$ & $1.1 \pm 0.1 \mathrm{a}$ \\
\hline
\end{tabular}

Values within columns with different letters are significantly different $(p<0.05)$.

botanicals have proven to be more effective in both laboratory and field trials where four botanicals caused over $90 \%$ FAW larval mortality at $72 \mathrm{~h}$ after application as compared to malathion that caused a moderate mortality of $51.7 \%$, while carbaryl was less effective with only $28 \%$ mortality [38]. Accordingly, the observed efficacy of the West African black pepper extract against FAW is likely due to plant secondary metabolites isobutyl amides with active ingredients (e.g., natural lipophilic amides, piperine, and piperiline) as a neurotoxin and deterrent [39]. High levels of antifeedant secondary compounds were reported in plants in the Piperaceae family that deter herbivores [40]. Similarly, significantly high FAW mortality of 3.3-96.7\% was reported due to hexane extracts of West African black pepper, which contain higher phenylpropanoid content that inhibited the functioning of cytochrome P450 [34]. The relatively low FAW severity and maize infestation observed for the beans intercropping systems support the hypothesis of this study and are likely due to the confusing olfactory and visual cues received from the companion beans plants that probably served as the push component that repelled FAW larvae away from the maize plants. In addition, the adverse effect of beans push cropping systems also supports the hypothesis of this study, which was likely mediated through allelopathic mechanisms whereby green leaf volatiles emitted by the companion beans crops repel the FAW larvae away from maize plants [25]. The beans root exudates may also contain novel flavonoid compounds that can disrupt the pupating phase of the FAW life cycle in soil and alter the pest ecology.
Also, beans as companion crops likely provided a different ecological niche for FAW larvae while emitting semiochemicals that deterred oviposition and FAW on maize [35]. Hence, the repellent and/or attractant ability of beans plants is a comparable FAW control measure to synthetic insecticide and the West African black pepper extract. Therefore, an integrated management approach involving both botanicals and beans intercropping systems could be a viable sustainable alternative FAW control strategy in maize fields [41].

\subsection{Impact of FAW Severity and Infestation on Maize Yield.} The low maize yield recorded in the control without any FAW control measure is consistent with the FAW severity and maize infestation, which likely reduced photosynthetic carbon fixation and consequently reduced plant growth and productivity $[42,43]$. Meanwhile, the low pest infestation recorded for the West African black pepper extract and synthetic insecticide likely allowed more crop growth and photosynthesis that resulted in higher maize yield [44]. Nonetheless, the lack of significant difference in the maize grain yield between the West African black pepper extract and synthetic insecticide treatments highlights the effectiveness of the West African black pepper extract as a sustainable alternative control measure against FAW. The observed efficacy of the West African black pepper extract is consistent with the reported efficacy on other crop pests [31] and commensurate with other reports on the effectiveness of some botanicals as control measures for fall armyworm in maize fields [38, 45]. Overall, the maize yield is consistent with the infestation rate and increased as the rate of infestation decreased and vice versa, which strongly support the hypothesis of this study. Besides the ability to control insect pests, beans biomass contributed significant amount of nitrogen via biological nitrogen fixation that enhanced soil fertility and plant nutrition $[46,47]$, which might have also enhanced the maize yield in the intercropped plots in this study. Furthermore, addition of organic matter and other nutrients by the nutrient-rich decomposing beans biomass likely reduced soil P-sorption and enhanced soil biota and nitrogen fixation that probably favoured maize 
growth and productivity. Moreover, soil organic carbon drives most microbial-mediated processes including soil respiration, nitrogen mineralization, and nutrient cycling and uptake by plants $[48,49]$. Hence, the improved maize yield in the plots intercropped with beans could be due to a combination of low fall armyworm severity and maize infestation and improved maize nutrition resulting from nitrogen fixation by the companion beans plants.

\section{Conclusion}

Our results highlight the efficacy of the West African black pepper extract as a viable botanical insecticide and beans intercropping as a sustainable push cropping system for the control of fall armyworm leading to a greater maize yield. The West African black pepper extract and beans push cropping system direct mortality or repellent effects on FAW. Although there was no significant difference between the dwarf and climbing beans intercrops, the dwarf beans intercrop is preferable because of the relative difficulty involved in managing the climbing beans vines on plants that may eventually limit maize growth and productivity. Maize yield demonstrated an inverse relationship with FAW severity and infestation as the highest maize yield occurred in the West African black pepper extract and synthetic insecticide treatments followed by both dwarf and climbing beans intercrops, which reflected the low FAW severity and infestation. Overall, the extract of West African black pepper and beans intercropping systems could be adopted as sustainable alternative management strategies for the invasive fall armyworm across maize fields in Africa.

\section{Data Availability}

All the data used to support the findings of this study are included within the article.

\section{Conflicts of Interest}

The authors declare that they have no conflicts of interest.

\section{Acknowledgments}

The authors are grateful for research grants of the Faculty of Agriculture and Veterinary Medicine of the University of Buea and the Ministry of Higher Education of Cameroon. Christopher Ngosong received financial assistance from the Alexander von Humboldt Foundation, Germany.

\section{References}

[1] J. E. Cairns, J. Hellin, K. Sonder et al., "Adapting maize production to climate change in sub-Saharan Africa," Food Security, vol. 5, no. 3, pp. 345-360, 2013.

[2] A. Gunes, A. Inal, M. Alpaslan, F. Eraslan, E. G. BagcI, and N. Cicek, "Salicylic acid induced changes on some physiological parameters symptomatic for oxidative stress and mineral nutrition in maize (Zea mays L.) grown under salinity," Journal of Plant Physiology, vol. 164, no. 6, pp. 728-736, 2007.

[3] A. Chabi-Olaye, C. Nolte, F. Schulthess, and C. Borgemeister, "Effects of grain legumes and cover crops on maize yield and plant damage by Busseola fusca (Fuller) (Lepidoptera: Noctuidae) in the humid forest of southern Cameroon," Agriculture, Ecosystems \& Environment, vol. 108, no. 1, pp. 17-28, 2005.

[4] W. S. Tavares, M. A. Costa, I. Cruz, R. D. Silveira, J. E. Serrão, and J. C. Zanuncio, "Selective effects of natural and synthetic insecticides on mortality of Spodoptera frugiperda (Lepidoptera: Noctuidae) and its predator Eriopis connexa (Coleoptera: Coccinellidae)," Journal of Environmental Science and Health, Part B, vol. 45, no. 6, pp. 557-561, 2010.

[5] E. Stokstad, "New crop pest takes Africa at lightning speed," Science, vol. 356, no. 6337, pp. 473-474, 2017.

[6] S. J. Johnson, "Migration and the life history strategy of the fall armyworm, Spodoptera frugiperda in the Western Hemisphere," International Journal of Tropical Insect Science, vol. 8, no. 4-5-6, pp. 543-549, 1987.

[7] M. A. Pogue, "World revision of the genus Spodoptera guenée (Lepidoptera: Noctuidae)," Memoirs of the American Entomological Society, vol. 43, pp. 1-201, 2002.

[8] I. Cruz and F. T. Turpin, "Effects of Spodoptera frugiperda on different growth stages of corn," Pesquisa Agropecuária Brasileira, vol. 17, pp. 355-359, 1982.

[9] R. De Almeida Sarmento, R. W. de Souza Aguiar, S. M. J. Vieira, H. G. de Oliveira, and A. M. Holtz, "Biology review, occurrence and control of Spodoptera frugiperda (Lepidoptera: Noctuidae) in corn in Brazil," Bioscience Journal, vol. 18, pp. 41-48, 2002.

[10] E. M. Barros, J. B. Torres, J. R. Ruberson, and M. D. Oliveira, "Development of Spodoptera frugiperda on different hosts and damage to reproductive structures in cotton," Entomologia Experimentalis et Applicata, vol. 137, no. 3, pp. 237-245, 2010.

[11] K. L. Andrews, "The whorlworm, Spodoptera frugiperda, in central America and neighboring areas," The Florida Entomologist, vol. 63, no. 4, pp. 456-467, 1980.

[12] G. Goergen, P. L. Kumar, S. B. Sankung, A. Togola, and M. Tamò, "First report of outbreaks of the fall armyworm Spodoptera frugiperda (J. E. Smith) (Lepidoptera, Noctuidae), a new alien invasive pest in West and Central Africa," PLoS One, vol. 11, no. 10, Article ID e0165632, 2016.

[13] M. J. W. Cock, P. K. Beseh, A. G. Buddie, G. Cafá, and J. Crozier, "Molecular methods to detect Spodoptera frugiperda in Ghana, and implications for monitoring the spread of invasive species in developing countries," Scientific Reports, vol. 7, p. 4103, 2017.

[14] R. N. Nagoshi, G. Goergen, K. A. Tounou, K. Agboka, D. Koffi, and R. L. Meagher, "Analysis of strain distribution, migratory potential, and invasion history of fall armyworm populations in northern Sub-Saharan Africa," Scientific Reports, vol. 8, p. $3710,2018$.

[15] B. Sisay, J. Simiyu, E. Mendesil et al., "Fall armyworm, Spodoptera frugiperda infestations in east Africa: assessment of damage and parasitism," Insects, vol. 10, no. 7, p. 195, 2019.

[16] M. Tindo, A. Tagne, A. Tigui et al., "First report of the fall armyworm, Spodoptera frugiperda (Smith, 1797) (Lepidoptera, Noctuidae) in Cameroon," Cameroon Journal of Biological and Biochemical Sciences, vol. 25, pp. 30-32, 2017.

[17] A. F. Kuate, R. Hanna, A. R. P. Doumtsop Fotio et al., "Spodoptera frugiperda Smith (Lepidoptera:Noctuidae) in Cameroon: case study on its distribution, damage, pesticide use, genetic differentiation and host plants," PLoS One, vol. 14, no. 4, Article ID e0215749, 2019.

[18] C. J. Pérez, P. Alvarado, C. Narváez et al., “Assessment of insecticide resistance in five insect pests attacking field and vegetable crops in Nicaragua," Journal of Economic Entomology, vol. 93, no. 6, pp. 1779-1787, 2000. 
[19] Q. C. Xu, H. L. Xu, F. F. Qin, J. Y. Tan, G. Liu, and S. Fujiyama, "Relay-intercropping into tomato decreases cabbage pest incidence," Journal of Food, Agriculture and Environment, vol. 8, pp. 1037-1041, 2010.

[20] D. R. Cook, B. R. Leonard, and J. Gore, "Field and laboratory performance of novel insecticides against armyworms (Lepidoptera: Noctuidae)," Florida Entomologist, vol. 87, no. 4, pp. 433-439, 2004.

[21] L. P. Dalvi, G. S. Andrade, D. Pratissoli, R. A. Polanczyk, and R. L. de Melo, "Compatibility of biological agents to control Spodoptera frugiperda (Lepidoptera: Noctuidae)," Revista Agrarian, vol. 4, pp. 79-83, 2011.

[22] S. M. Cook, Z. R. Khan, and J. A. Pickett, "The use of push-pull strategies in integrated pest management," Annual Review of Entomology, vol. 52, no. 1, pp. 375-400, 2007.

[23] Z. R. Khan, C. A. O. Midega, A. Hassanali, J. A. Pickett, and L. J. Wadhams, "Assessment of different legumes for the control of Striga hermonthica in maize and sorghum," Crop Science, vol. 47, pp. 728-734, 2007.

[24] C. A. O. Midega, J. O. Pittchar, J. A. Pickett, G. W. Hailu, and Z. R. Khan, "A climate-adapted push-pull system effectively controls fall armyworm, Spodoptera frugiperda (J. E. Smith), in maize in East Africa," Crop Protection, vol. 105, pp. 10-15, 2018.

[25] Z. R. Khan, C. A. O. Midega, T. J. A. Bruce, A. M. Hooper, and J. A. Pickett, "Exploiting phytochemicals for developing a "push-pull" crop protection strategy for cereal farmers in Africa," Journal of Experimental Botany, vol. 61, no. 15, pp. 4185-4196, 2010.

[26] B. Ndakidemi, K. Mtei, and P. A. Ndakidemi, "Impacts of synthetic and botanical pesticides on beneficial insects," Agricultural Sciences, vol. 7, no. 6, pp. 364-372, 2016.

[27] J. Proctor, I. D. Edwards, R. W. Payton, and L. Nagy, "Zonation of forest vegetation and soils of mount Cameroon, West Africa," Plant Ecology, vol. 192, no. 2, pp. 251-269, 2007.

[28] B. Vanlauwe, A. Bationo, J. Chianu et al., "Integrated soil fertility management," Outlook on Agriculture, vol. 39, no. 1, pp. 17-24, 2010.

[29] C. B. Tanyi, C. Ngosong, and N. N. Ntonifor, "Comparative effects of Piper guineense emulsion and cabbage-tomato intercropping for controlling cabbage pests and improving performance," Journal of Agriculture and Ecology Research International, vol. 13, pp. 1-12, 2017.

[30] R. W. Payton, "Ecology, altitudinal zonation and conservation of tropical rainforest of mount Cameroon," Final projectreport. R4600, ODA, London, UK, 1993.

[31] P. J. Fraser, J. B. Hall, and J. R. Healing, Climate of the Mount Cameroon Region, Long and Medium Term Rainfall, Temperature and Sunshine Data, Vol. 56, SAFS, University of Wales Bangor, MCP-LBG, Limbe, Cameroon, 1998.

[32] T. H. Jarrod, M. L. Gus, and B. L. Rogers, "Fall armyworm (Lepidoptera: Noctuidae) ecology in southeastern cotton," Journal of Integrated Pest Management, vol. 6, p. 1, 2015.

[33] StatSoft, Statistica 9.1 for Windows, StatSoft Inc., Tusla, OK, USA, 2010.

[34] D. C. Lucena, L. R. Bertholdo-vargas, W. C. Silva et al., "Biological activity of piper aduncum extracts on anticarsia gemmatalis (hübner) (Lepidoptera: erebidae) and Spodoptera frugiperda (J. E. Smith) (Lepidoptera: Noctuidae)," Anais da Academia Brasileira de Ciências, vol. 89, no. 3, pp. 1869-1879, 2017.

[35] K. Chamberlain, Z. R. Khan, J. A. Pickett, T. Toshova, and L. J. Wadhams, "Diel periodicity in the production of green leaf volatiles by wild and cultivated host plants of stemborer moths, chilo partellus and Busseola fusca," Journal of Chemical Ecology, vol. 32, no. 3, pp. 565-577, 2006.

[36] A. Al-Sarar, F. R. Hall, and R. A. Downer, "Impact of spray application methodology on the development of resistance to cypermethrin and spinosad by fall armywormSpodoptera frugiperda (J. E. Smith)," Pest Management Science, vol. 62, no. 11, pp. 1023-1031, 2006.

[37] J. T. Hardke, J. H. Temple, B. R. Leonard, and R. E. Jackson, "Laboratory toxicity and field efficacy of selected insecticides against fall armyworm (Lepidoptera: Noctuidae)1," Florida Entomologist, vol. 94, no. 2, pp. 272-278, 2011.

[38] B. Sisay, T. Tefera, M. Wakgari, G. Ayalew, and E. Mendesil, "The efficacy of selected synthetic insecticides and botanicals against fall armyworm, Spodoptera frugiperda, in maize," Insects, vol. 10, no. 2, p. 45, 2019.

[39] V. F. d. Paula, L. C. d. A. Barbosa, A. J. Demuner, D. PilóVeloso, and M. C. Picanço, "Synthesis and insecticidal activity of new amide derivatives of piperine," Pest Management Science, vol. 56, no. 2, pp. 168-174, 2000.

[40] L. A. Dyer, C. D. Dodson, J. Beihoffer, and D. K. Letourneau, "Trade-offs in anti-herbivore defenses in Piper cenocladum: ant mutualists versus plant secondary metabolites," Journal of Chemical Ecology, vol. 27, no. 3, pp. 581-592, 2001.

[41] R. Day, P. Abrahams, M. Bateman et al., "Fall armyworm: impacts and implications for Africa," Outlooks on Pest Management, vol. 28, no. 5, pp. 196-201, 2017.

[42] L. A. Dyer, C. D. Dodson, J. O. Stireman III et al., "Synergistic effects of three Piper amides on generalists and specialist hervivores," Journal of Chemical Ecology, vol. 29, no. 11, pp. 2499-2514, 2003.

[43] M. S. Silva, S. M. F. Broglio, R. C. Prédes Trindade, E. S. Ferrreira, I. B. Gomes, and L. B. Micheletti, "Toxicity and application of neem in fall armyworm," Comunicata Scientiae, vol. 6, no. 3, pp. 359-364, 2015.

[44] I. K. Pavel, F. Brian, H. F. Christine, and D. H. Robert, "Plant responses to insect herbivory: interactions between photosynthesis, reactive oxygen species and hormonal signaling pathways," Journal of Plant, Cell and Environment, vol. 35, pp. 441-453, 2012.

[45] A. J. Mordue and A. J. Nisbet, "FORUM azadirachtin from the neem tree Azadirachta indica: its action against insects," Annals of Sociology and Entomology Brasil, vol. 29, pp. 615631, 2000.

[46] K. E. Giller, Nitrogen Fixation in Tropical Cropping Systems, CAB International, Wallingford, UK, 2001.

[47] N. Bildirici and N. Yilmaz, "The effect of different nitrogen and phosphorus doses and bacteria inoculation (Rhizobium phaseoli) on the yield and yield components of field bean (Phaseolus vulgaris L.)," Journal of Agronomy, vol. 4, pp. 207-215, 2005.

[48] P. Hinsinger, "Bioavailability of soil inorganic P in the rhizosphere as affected by root-induced chemical changes: a review," Plant and Soil, vol. 237, no. 2, pp. 173-195, 2001.

[49] S. Fontaine, A. Mariotti, and L. Abbadie, "The priming effect of organic matter: a question of microbial competition?" Soil Biology and Biochemistry, vol. 35, no. 6, pp. 837-843, 2003. 